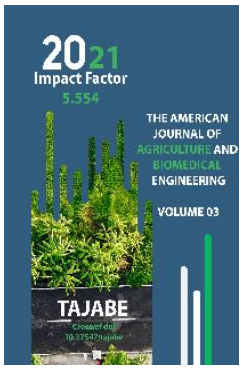

Journal Website: http://theamericanjour nals.com/index.php/taj abe

Copyright: Original content from this work may be used under the terms of the creative commons attributes 4.0 licence.

\section{Study And Evaluation Of Key Indicators Of Quality And Safety Of Oil And Fat Products}

\author{
Muminov Najmiddin Shamsiddinovich \\ Doctor Of Technical Sciences, Head Of The Department Of Standardization And Certification \\ Of Agricultural Products, Tashkent State Agrarian University, Tashkent, Uzbekistan \\ Kurambaev Muzaffar Mamatjanovich \\ Master Of The Department Of Standardization And Certification Of Agricultural Products, \\ Tashkent State Agrarian University, Tashkent, Uzbekistan \\ Rajabov Sardor Jumaboy O'g'li \\ Master Of The Department Of Standardization And Certification Of Agricultural Products, \\ Tashkent State Agrarian University, Tashkent, Uzbekistan \\ Akobirova Nodira \\ Researcher, Tashkent State Agrarian University, Tashkent, Uzbekistan
}

\title{
ABSTRACT
}

The article deals with the basic terms and definitions of oil and oil products, technological processes, their classification, safety requirements, sanitary norms and rules, permissible levels of hazardous substances, requirements for production processes, packaging and labeling requirements. , as well as identification and conformity assessment processes. All of these processes are the basis for the production of oil and oil products and the provision of quality and safety indicators.

\section{KEYWORDS}

Consumable oil, nutritional value, quality, product safety, sanitary norms and regulations, production processes, packaging, marking, identification, conformity assessment, standard, technical regulation.

\section{INTRODUCTION}

The problem of food quality and safety is a complex problem that requires a lot of effort to solve, both raw material suppliers and scientists - biochemists, microbiologists and manufacturers, technologists, engineers, sanitary-epidemiologists services, government agencies and of course consumers. The urgency of the problem of food quality and safety is growing every year, as it is the quality and safety of food that is one of the key factors determining human health and the preservation of the gene pool.

In modern economic conditions, product quality has become the most important factor in the competitiveness of the enterprise. Naturally, in market relations, the manufacturer strives to achieve sustainable 
quality of its products, using all the tools developed by global and local practice. One of the urgent tasks of food safety is to study and analyze best practices in the field of production, processing and quality assessment, as well as the sale of safe food products to the population. It is necessary to ensure that they are evaluated for quality and safety in accordance with the requirements of international standards, using modern testing methods and measuring and testing tools [13]. The purpose of this scientific article is to describe and evaluate the quality of various consumable oils in accordance with the characteristics consumed and the requirements of applicable standards and technical regulations.

\section{Terms and definitions related to oil products, technological processes:}

Fat and oil products - nutritional supplements and other ingredients based on vegetable oils or vegetable fats and animal fats and oils (including marine mammalian and fish oils), vegetable oils and products obtained with or without the addition of water;

Edible fat and fat products - fat and fat products used for cooking or in various branches of the food industry.

Oily raw materials - seeds and fruits of oily plants, oily parts of plant species;

Vegetable oil - a mixture of glycerides of fatty acids and related substances, extracted from fatty raw materials, with a fat content of not less than 99 percent;

margarine - with or without the addition of animal fats or their mixtures of modified and (or) unmodified vegetable oils, with or without the addition of water, milk and (or) processed products, as well as nutritional supplements and ingredients with a mass fraction of fat not less than 20 percent prepared emulsion high-dispersion oil product;

Mayonnaise - the same emulsified product of the lower dispersion prepared with or without the addition of refined, deodorized vegetable oils, water, egg products in the amount of not less than 1 percent when converted to egg yolk (dry), processed dairy products, nutritional supplements and other nutritional ingredients;

Household soap - a product consisting of sodium or potassium salts of natural fatty acids, with the addition of synthetic, resinous or naphthenic fatty acids (with or without them) and other additives to improve the consumer properties.

Refining - the following purification processes of products derived from the processing of vegetable oils and (or) fats, (or) animal fats and vegetable oils: hydration, neutralization, washing, drying, bleaching, filtration, deodorization or degreasing of fats and (or) animal fats consists of a complex of some of these processes according to the application of fats and products derived from the processing of vegetable oils;

Hydration - processing of phosphoruscontaining substances in vegetable oils and (or) fats by chemical, mechanical and other means;

Deodorization - removal of volatile, odorous and flavoring substances under vacuum with 
The American Journal of Agriculture and Boimedical Engineering (ISSN - 2689-1018)

heated steam from vegetable oils and (or) fats;

Neutralization by distillation - a hightemperature process of removal of free fatty acids, odorants and other volatile substances by driving under vacuum with heated steam;
Distillation - the process of purification by evaporation and condensation of the formed vapors;

Fractionation - is the thermomechanical separation of vegetable oils into fractions.

Table 1. Types of vegetable oils depending on the source of fatty raw materials

\begin{tabular}{|c|c|c|c|}
\hline$T / r$ & Types of oils & Name of raw material & Botanical name \\
\hline 1. & Apricot oil & Apricot (bean seed) & $\begin{array}{l}\text { Prunus armeniaca Linnaeus: syn. } \\
\text { Armeniaca vulgaris Lamarck }\end{array}$ \\
\hline 2. & Peanut Butter & Peanut & Arachis hypogaea Linnaeus \\
\hline 3. & Watermelon oil & Watermelon (seeds) & $\begin{array}{l}\text { Citrullus lanatus (Thumb.) Matsumet Nakai } \\
\text { Citrullus spp. }\end{array}$ \\
\hline 4. & Birch oil & Birch & Fagus sylvatica Linnaeus \\
\hline 5 . & Grape oil & Grapes (seeds) & Vitis vinifera Linnaeus \\
\hline 6. & Cherry oil & Cherry (bean seed) & Prunus cerasus LinnaeusRosaceae \\
\hline 7. & $\begin{array}{c}\text { Mustard oil: } \\
\text { brown; } \\
\text { Indian; } \\
\text { black; } \\
\text { white mustard oil; } \\
\text { field mustard oil. }\end{array}$ & $\begin{array}{l}\text { Mustard (seed): } \\
\text { brown; } \\
\text { Indian; } \\
\text { black; } \\
\text { white; } \\
\text { field. }\end{array}$ & $\begin{array}{l}\text { Brassica Linnaeusjuncea Czernajawet } \\
\text { cossonnigraW.D.J. Koch } \\
\text { Sinapis alba Linnaeus Sinapis arvensis } \\
\text { Linnaeus }\end{array}$ \\
\hline 8. & Cedar oil & Cedar (walnut) & Pinus cembra L. \\
\hline 9. & Coconut oil & Copra & Cocos nucifera Sinapis Linnaeus \\
\hline 10. & Corn oil & Corn (seeds) & Zea mays Linnaeus \\
\hline
\end{tabular}


The American Journal of Agriculture and Boimedical Engineering (ISSN - 2689-1018)

\begin{tabular}{|c|c|c|c|}
\hline 11. & Sesame oil & Sesame seeds & Sesamum indicum Linnaeus \\
\hline 12. & Kanakunjut oil & Kanakunjut (seeds) & Ricinus communis Linnaeus \\
\hline 13. & Flaxseed oil & Flaxseed (seeds) & Linumusilatissimum Linnaeus \\
\hline 14. & Almond oil & $\begin{array}{l}\text { Bitter almonds } \\
\quad \text { (walnuts) }\end{array}$ & $\begin{array}{l}\text { Prunus dulcis (Miller) DA. Webb var. amara } \\
\text { (DeConaolle) Buchheim: } \\
\text { syn. Prunus amygdalusBatsch var. amara } \\
\text { (DeConaolla) Focke }\end{array}$ \\
\hline 15. & Walnut oil & Walnut (seeds) & $\begin{array}{l}\text { Aleurites moluccana (Linnaeus), } \\
\text { Wildenow. syn.Aleurites triloba Juglans } \\
\text { regia Linnaeus }\end{array}$ \\
\hline 16. & Olive oil & $\begin{array}{l}\text { Olive (core) } \\
\text { Olive (pericarp }\end{array}$ & Olea europaea Linnaeus \\
\hline 17. & Palm oil & $\begin{array}{l}\text { Oily palm (pericarp of } \\
\text { the fruit) }\end{array}$ & Elaeisguineensis Jacquin. \\
\hline 18. & Palm oil & Oily palm (bean seeds) & Elaeisguineensis Jacquin. \\
\hline 19. & Peach Oil & Peaches (seeds) & Prunus persica (hinnacus) Batsch \\
\hline 20. & Sunflower oil & Sunflower (seeds) & Helianthus annuusLinnaeus \\
\hline 21. & Wheat oil & Soft wheat (grain) & $\begin{array}{l}\text { Triticum aestivum Linnaeus: emened. Fiori } \\
\text { et Paoletti } \\
\text { Triticum durum Desfontaines }\end{array}$ \\
\hline 22. & Rapeseed oil & Rapeseed (seeds) & Brassica napus Linnaeus \\
\hline 23. & Rice oil & Rice & Oryza sativa Linnaeus \\
\hline 24. & Maxsar oil & Maxsar (seeds) & Carthamustinctorius Linnaeus \\
\hline 25. & Plum oil & Plum (bean seeds) & Prunus domestica Linnaeus \\
\hline 26. & Soybean oil & Soybeans & Glycine max (Linnaeus) Merrill \\
\hline
\end{tabular}


The American Journal of Agriculture and Boimedical Engineering (ISSN - 2689-1018)

\begin{tabular}{|c|c|c|c|}
\hline 27. & Tomato oil & Tomato (seeds) & $\begin{array}{c}\text { Lycopersicon } \\
\text { lycopersikum (Linnaeus), Karsten ex } \\
\text { Farwell syn, Lycopersicon }\end{array}$ \\
\hline 28. & Cumin oil & Cumin (seeds) & Csculentum P. Miller; \\
\hline 29. & Pumpkin oil & Pumpkin (seeds) & $\begin{array}{c}\text { Cucurbita maxima A.N. Duchesne } \\
\text { Cucurbita pepo (Linnaeus) }\end{array}$ \\
\hline 30. & Cottonseed oil & Cotton (seeds) & Cossypium spp. \\
\hline 31. & Hemp Oil & Hemp Seeds & Cannabis ruderalis \\
\hline
\end{tabular}

\section{RESEARCH METHODS}

Safety requirements for fat and oil products: Non-edible fat and fat products during the shelf life of edible fat and fat products using the fat and fat products in circulation for the specified purpose must not harm human life and health during storage [4-7].

During the production, packaging, storage, transportation, circulation and utilization (processing) of petroleum products must comply with the requirements of sanitary rules, norms and hygienic standards, which must be complied with, established by the Technical Regulation.

Sanitary rules, norms and hygienic standards: Toxic elements of food fats, mycotoxins and radionuclides, pesticides, antibiotics, dioxins, transisomers of fatty acids, indicators of oxidative degradation, benz (a) pyrene, cyanide, erucic acid and gossypol should not be higher than the given level.

Table 2. Permissible amount of toxic elements in dietary fats and oils

\begin{tabular}{|c|c|c|}
\hline \multirow{2}{*}{ Product Name } & Indications & $\begin{array}{c}\text { Fixed amount not more than } \mathrm{mg} / \\
\mathrm{kg}\end{array}$ \\
\hline \multirow{2}{*}{$\begin{array}{c}\text { Vegetable oils (all types), fractions } \\
\text { of vegetable oils. }\end{array}$} & Lead & 0,1 \\
\cline { 2 - 3 } & Margimush & 0,2 (for peanut butter) \\
\cline { 2 - 3 } & Man & 0,1 \\
\hline
\end{tabular}




\begin{tabular}{|c|c|c|}
\hline & Cadmium & 0,05 \\
\hline & Mercury & 0,03 \\
\hline & \multirow[b]{2}{*}{ Iron } & 1,5 for refined oils \\
\hline & & $\begin{array}{l}\text { 5,0 for a mixture of unrefined oils, } \\
\text { refined and unrefined oils }\end{array}$ \\
\hline & \multirow{2}{*}{ Copper } & 0,1 for refined oils \\
\hline & & 0,4 for unrefined oils \\
\hline \multirow{5}{*}{$\begin{array}{l}\text { Refined deodorized hydrogenated } \\
\text { oils (fats); } \\
\text { refined deodorized pereterified oils } \\
\text { (fats); } \\
\text { special oils (bread, confectionery, } \\
\text { baking oils, etc.). }\end{array}$} & Lead & 0,1 \\
\hline & Margimush & 0,1 \\
\hline & Cadmium & 0,05 \\
\hline & Mercury & 0,05 \\
\hline & Nickel & $\begin{array}{c}0,7 \\
\text { hydrogenated refined and } \\
\text { deodorized oils (fats) and products } \\
\text { containing hydrogenated oils and } \\
\text { fats учун }\end{array}$ \\
\hline \multirow{7}{*}{ Margarines. } & Lead & 0,1 \\
\hline & Margimush & 0,1 \\
\hline & Cadmium & 0,05 \\
\hline & Mercury & 0,05 \\
\hline & Nickel & $\begin{array}{l}\text { 0,7 products containing } \\
\text { hydrogenated oils and fats }\end{array}$ \\
\hline & Iron & $\begin{array}{c}1,5 \text { (except margarines with cocoa } \\
\text { products) }\end{array}$ \\
\hline & Copper & 0,1 (except margarines with cocoa \\
\hline
\end{tabular}


The American Journal of Agriculture and Boimedical Engineering (ISSN - 2689-1018)

\begin{tabular}{|c|c|c|}
\hline & & products) \\
\hline Milk fat substitutes; & Lead & 0,1 \\
\hline Cocoa butter equivalent; & Margimush & 0,1 \\
\hline SOS-type cocoa butter enhancers; & Cadmium & 0,05 \\
\hline POP-type cocoa butter substitutes; & Mercury & 0,05 \\
\hline $\begin{array}{l}\text { Nolaurin non-tempered cocoa oil } \\
\text { substitutes; }\end{array}$ & & 0,7 \\
\hline $\begin{array}{l}\text { Laurin type non-tempered cocoa } \\
\text { butter substitutes. }\end{array}$ & Nickel & $\begin{array}{c}\text { таркибида } \\
\text { гидрогенизацияланганмойлар ва } \\
\text { ёғлар мавжуд махсулотлар }\end{array}$ \\
\hline Mayonnaise; & Lead & 0,3 \\
\hline mayonnaise sauces; & Margimush & 0,1 \\
\hline vegetable oil-based sauces; & Cadmium & 0,05 \\
\hline cream based on vegetable oils. & Mercury & 0,05 \\
\hline \multirow{10}{*}{$\begin{array}{l}\text { Vegetable-oil spreads; } \\
\text { vegetable-butter spreads; } \\
\text { vegetable oil melted mixtures; } \\
\text { vegetable-butter melted mixtures. }\end{array}$} & \multirow{2}{*}{ Lead } & 0,1 \\
\hline & & 0,3 for cocoa product added types \\
\hline & Margimush & 0,1 \\
\hline & \multirow{3}{*}{ Cadmium } & 0,03 for vegetable-butter products \\
\hline & & 0,05 for vegetable oils \\
\hline & & 0,2 for cocoa product added types \\
\hline & \multirow{3}{*}{ Mercury } & 0,03 for vegetable-butter products \\
\hline & & 0,05 for vegetable oils \\
\hline & & 0,2 for cocoa product added types \\
\hline & Nickel & $\begin{array}{l}0,7 \text { products containing } \\
\text { hydrogenated oils and fats }\end{array}$ \\
\hline
\end{tabular}




\begin{tabular}{|c|c|c|}
\hline & Iron & $\begin{array}{l}1,5 \text { (except for spreads and melted } \\
\text { mixes with cocoa product) }\end{array}$ \\
\hline & \multirow{2}{*}{ Copper } & $\begin{array}{l}0,1 \text { for vegetable oils (except cocoa } \\
\text { products) }\end{array}$ \\
\hline & & $\begin{array}{l}\text { 0,4 for vegetable-butter types } \\
\text { (except for cocoa products) }\end{array}$ \\
\hline \multirow{3}{*}{ Distilled glycerin. } & Iron & 2,0 \\
\hline & Lead & 5,0 \\
\hline & Margimush & 0,3 \\
\hline
\end{tabular}

Table 3. Residual content of pesticides in oil products, permissible levels of radionuclides, mycotoxins, antibiotics and dioxins

\begin{tabular}{|c|c|c|}
\hline Product name & Indicators & $\begin{array}{c}\text { The permissible amount is } \\
\text { not more than } \mathrm{mg} / \mathrm{kg}\end{array}$ \\
\hline Vegetable oils (all types), & $\begin{array}{l}\text { Mycotoxins: } \\
\text { aflatoxin } \mathrm{V}_{1}\end{array}$ & $\begin{array}{c}0,005 \\
\text { (except refined oils) }\end{array}$ \\
\hline $\begin{array}{l}\text { refined deodorized hydrogenated oils } \\
\text { (fats); }\end{array}$ & $\begin{array}{l}\text { Radionuclides: } \\
\text { cesium-137 }\end{array}$ & $\begin{array}{c}40 \mathrm{Bk} / \mathrm{kg} \text { (for vegetable } \\
\text { oils) }\end{array}$ \\
\hline refined deodorized pereeterified oils & strontium-90 & $60 \mathrm{Bk} / \mathrm{kg}$ \\
\hline $\begin{array}{c}\text { (fats); special oils (bread, } \\
\text { confectionery, baking oils, etc.); } \\
\text { margarines; }\end{array}$ & $\begin{array}{c}\text { Pesticides: } \\
\text { GXTsG (abg-isomers) }\end{array}$ & $\begin{array}{l}0,05 \text { (for refined oils)0,2 } \\
\quad \text { (for unrefined oils) }\end{array}$ \\
\hline mayonnaise; & DDT and its metabolites & $\begin{array}{l}0,1 \text { (for refined oils)o, } 2 \\
\text { (for unrefined oils) }\end{array}$ \\
\hline milk fat substitute suppressors; & Polychlorinated biphenyls & $\begin{array}{l}\qquad 3,0 \\
\text { (for products containing }\end{array}$ \\
\hline
\end{tabular}


The American Journal of Agriculture and Boimedical Engineering (ISSN - 2689-1018)

Published: June 28, 2021| Pages: 13-29

Doi: https://doi.org/10.37547/tajabe/Volume03Issueo6-03

OCLC - 1121105746

\begin{tabular}{|c|c|c|}
\hline cocoa butter equivalent; & & fish oil) \\
\hline $\begin{array}{l}\text { SOS-type cocoa butter enhancers; } \\
\text { POP-type cocoa butter substitutes; } \\
\text { Nolaurin type non-tempered cocoa } \\
\text { butter substitutes; } \\
\text { Laurin type non-tempered cocoa } \\
\text { butter substitutes. }\end{array}$ & Dioxins & $\begin{array}{l}0,00000075 \\
01.01 .2021 \text { (recalculated to } \\
\text { the amount of fat in the } \\
\text { product for vegetable } \\
\text { oils) The probability of its } \\
\text { presence in the oil is } \\
\text { determined in cases } \\
\text { where it is reasonably } \\
\text { assumed }\end{array}$ \\
\hline \multirow{4}{*}{$\begin{array}{l}\text { vegetable oil-melted mixtures; } \\
\text { vegetable-butter spreads; } \\
\text { vegetable-butter melted mixtures. }\end{array}$} & $\begin{array}{l}\text { Mycotoxins: } \\
\text { aflatoxin V1 }\end{array}$ & 0,005 \\
\hline & $\begin{array}{l}\text { Radionuclides: } \\
\text { cesium-137 } \\
\text { Strontium-90 }\end{array}$ & $\begin{array}{c}100 \mathrm{Bk} / \mathrm{kg} \\
\text { (for vegetable butter } \\
\text { products) } \\
60 \mathrm{Bk} / \mathrm{kg} \text { (for vegetable } \\
\text { oil products) } \\
80 \mathrm{Bk} / \mathrm{kg}\end{array}$ \\
\hline & GXTsG (abg isomers) & $\begin{array}{l}\text { When recalculating the } \\
\text { amount of fat } 1,25 \text { (for } \\
\text { vegetable oil products) } \\
0.05 \text { (for vegetable oil } \\
\text { products) }\end{array}$ \\
\hline & DDT and its metabolites & $\begin{array}{l}\text { When recalculated to the } \\
\text { amount of fat } \\
1.0 \text { (for vegetable oil } \\
\text { products) } \\
0.1 \text { (for vegetable oil } \\
\text { products) }\end{array}$ \\
\hline
\end{tabular}


The American Journal of Agriculture and Boimedical Engineering (ISSN - 2689-1018)

\begin{tabular}{|c|c|c|}
\hline & $\begin{array}{c}\text { Antibiotics ** (for } \\
\text { vegetable-butter } \\
\text { products) }\end{array}$ & not allowed \\
\cline { 2 - 3 } & $\begin{array}{c}\text { chloramphenicol } \\
\text { (chloramphenicol) }\end{array}$ & not allowed \\
& Tetracycline group & $<0.01 \mathrm{mg} / \mathrm{kg}$ \\
\hline & not allowed \\
streptomycin & $<0.2 \mathrm{mg} / \mathrm{kg}$ \\
\hline & not allowed \\
& $<0.004 \mathrm{mg} / \mathrm{kg}$ \\
\hline
\end{tabular}

Table 4. Residual content of pesticides in oil products, permitted drugs of radionuclides, mycotoxins, antibiotics and dioxins

\begin{tabular}{|c|c|c|}
\hline Product name & Indicators & $\begin{array}{c}\text { The permissible amount is } \\
\text { not more than } \mathrm{mg} / \mathrm{kg}\end{array}$ \\
\hline \multirow{4}{*}{$\begin{array}{l}\text { refined deodorized hydrogenated } \\
\text { oils (fats); } \\
\text { refined deodorized pereeterified } \\
\text { oils (fats); oils for special use } \\
\text { (bread, confectionery, baking oils, } \\
\text { etc.); }\end{array}$} & $\begin{array}{l}\text { Mycotoxins: } \\
\text { aflatoxin V1 }\end{array}$ & $\begin{array}{c}0,005 \\
\text { (except refined oils) }\end{array}$ \\
\hline & $\begin{array}{l}\text { Radionuclides: } \\
\text { cesium-137 }\end{array}$ & $\begin{array}{c}40 \mathrm{Bk} / \mathrm{kg} \text { (for vegetable } \\
\text { oils) } 60 \mathrm{Bk} / \mathrm{kg}\end{array}$ \\
\hline & strontium-90 & $80 \mathrm{Bk} / \mathrm{kg}$ \\
\hline & $\begin{array}{c}\text { Pesticides: } \\
\text { GXTsG (abg-isomers) }\end{array}$ & $\begin{array}{l}0.05 \text { (for refined oils) } 0.2 \\
\quad \text { (for unrefined oils) }\end{array}$ \\
\hline margarines; mayonnaise; & DDT and its metabolites & 0.1 (for refined oils) 0.2 (for \\
\hline
\end{tabular}


The American Journal of Agriculture and Boimedical Engineering (ISSN - 2689-1018)

\begin{tabular}{|c|c|c|}
\hline \multirow[b]{2}{*}{$\begin{array}{l}\text { cream based on vegetable oils; } \\
\text { milk fat substitutes; }\end{array}$} & & unrefined oils) \\
\hline & Polychlorinated biphenyls & $\begin{array}{c}3,0 \\
\text { (for products containing fish } \\
\text { oil) }\end{array}$ \\
\hline $\begin{array}{l}\text { sauce-type cocoa butter } \\
\text { enhancers; POP-type cocoa butter } \\
\text { substitutes; } \\
\text { Nolaurin type non-tempered cocoa } \\
\text { butter substitutes; Laurin type } \\
\text { non-tempered cocoa butter } \\
\text { substitutes. }\end{array}$ & Dioxins & $\begin{array}{l}0,00000075 \\
\text { 01.01.2021 Effective from } \\
\text { (recalculated to the amount } \\
\text { of fat in the product for } \\
\text { vegetable oils) The } \\
\text { probability of its presence in } \\
\text { the oil is determined in cases } \\
\text { where it is reasonably } \\
\text { assumed }\end{array}$ \\
\hline \multirow{4}{*}{$\begin{array}{c}\text { Vegetable-oil spreads; } \\
\text { vegetable oil-melted mixtures; } \\
\text { vegetable-butter spreads; } \\
\text { vegetable-butter melted mixtures. }\end{array}$} & $\begin{array}{l}\text { Mycotoxins: } \\
\text { aflatoxin } \mathrm{V}_{1}\end{array}$ & 0,005 \\
\hline & $\begin{array}{l}\text { Radionuclides: } \\
\text { cesium-137 } \\
\text { Strontium-90 }\end{array}$ & $\begin{array}{c}100 \mathrm{Bk} / \mathrm{kg} \\
\text { (for vegetable butter } \\
\text { products)60 Bk/ kg } \\
\text { (for vegetable oil products) } \\
80 \mathrm{Bk} / \mathrm{kg}\end{array}$ \\
\hline & GXTsG (abg-isomers) & $\begin{array}{l}\text { When recalculated to the } \\
\text { amount of fat } \\
1.25 \text { (for vegetable-butter } \\
\text { products) } 0.05 \text { (for } \\
\text { vegetable oil products) }\end{array}$ \\
\hline & DDT and its metabolites & $\begin{array}{l}\text { Calculated to the amount of } \\
\text { fat } \\
1.0 \text { (for vegetable-butter }\end{array}$ \\
\hline
\end{tabular}




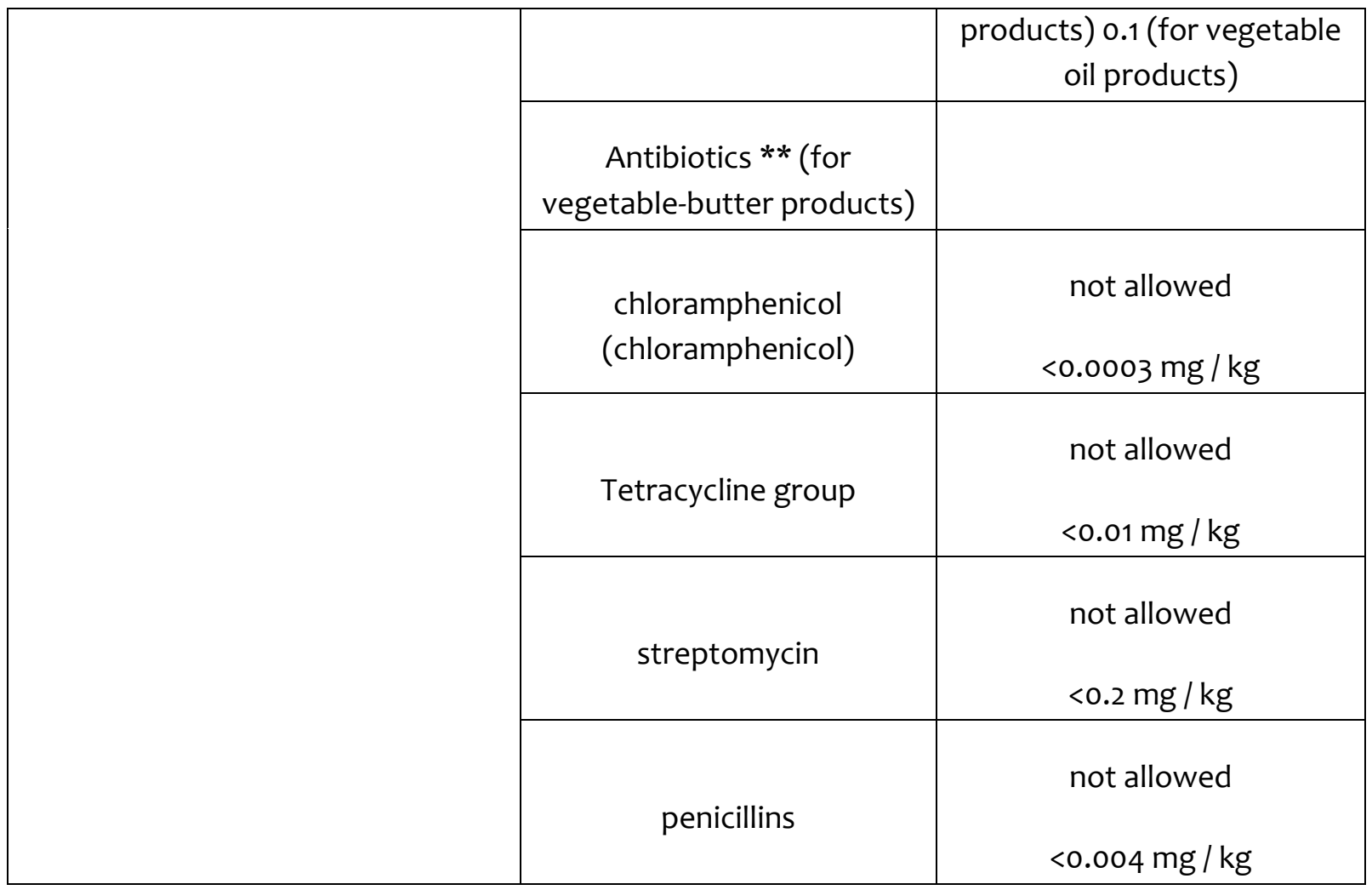

Requirements for the production of petroleum products: Excludes contamination of production facilities (shops, warehouses, departments and other buildings) and technological equipment used in the production of petroleum products, raw materials, semi-finished products and finished petroleum products should be in position.

In the production (preparation) of feed oil and fat products related to safety requirements,

manufacturers must develop, implement and enforce procedures based on the principles of XACCP (Hazard Analysis and Critical Control Points) [8-11]. Technological processes for the production of petroleum products must be carried out in accordance with the procedures and conditions established by the regulations in the field of technical regulation to prevent contamination of raw materials, semi-finished products and finished products. Enterprises producing petroleum products must pass an environmental impact assessment in the manner prescribed by law and comply with environmental standards approved by the competent authority. Raw materials, ingredients, feed additives, technological means used in the production of petroleum products must comply with the requirements of regulatory documents in the field of technical regulation.

The safety of oil products in the production process must be ensured as follows:

a) Selection of technological processes and methods of their implementation at all stages (departments) of production of oil products;

b) Selection of the optimal sequence of technological processes that exclude contamination of food and oil products; 
c) Control over the operation of process equipment;

d) Ensuring the safety of raw materials and feed additives required for the production of oil and fat products;

e) Storage of oil production facilities, process equipment and equipment used in conditions that exclude contamination of feed oil products;

f) Selection of methods and sequence of sanitary cleaning, disinfection, disinsection and deratization of production facilities, sanitary cleaning and disinfection of technological equipment and devices used in the production of oil products.

Sanitary cleaning of production facilities and process equipment, the sequence of disinfection, disinsection and deratization should be determined at intervals that exclude the risk of contamination of oil products. The sequence of cleaning operations is determined by the manufacturer.

\section{Requirements for packaging of fat and oil} products: The packaging of fat products, the shelf life of edible fat products and the shelf life of non-edible fat products should ensure that product safety and identification marks do not change during handling.

In case of damage to the consumer packaging of edible oil and fat products, it must be withdrawn from circulation by the owner of fatty products independently or on the notice of the competent authorities.

Packaging in contact with oil products (materials used for packaging) must comply with the requirements of the General
Technical Regulation on the safety of packaging in contact with food.

Used packaging material must be able to be recycled, disposed of and destroyed in order to ensure human life, health and environmental safety.

Requirements for the marking of oil products: The marking of oil products is carried out in accordance with the requirements of the General Technical Regulation on the safety of food products.

Information on the labeling of food and fat products shall be stated in the state language. This information may also be expressed in other languages, provided that its content is the same as the content of the information in the state language.

The marking on the packaging of edible oil and fat products must be clear, easy to read, clear and not confusing to consumers, while the inscriptions, signs, symbols must differ from the background on which the marking is placed [10-13]. The nutritional value of fat products (energy value per 100 grams of product, proteins, fats, carbohydrates, vitamins, macro- and micronutrients) is indicated. Information on the energy value of proteins, fats, carbohydrates and calories is given in cases where their value per 100 grams of food is at least $2 \%$, at least $5 \%$ of the recommended daily intake for minerals and vitamins.

Information on the presence of genetically modified organisms for imported fats and oils is provided in accordance with the requirements of the legislation. 
In the information provided to the consumer, the volume and basic dimensions of fat and oil products, gross, net mass are indicated on the package (container) in the metric measurement system (International System of Units).

The date of manufacture (manufacture) of fat and oil products is indicated on the label or on the packaging (container) with the words "Manufactured (manufactured ...) (date)".

Requirements for storage of oil products: Storage of oil products should be carried out in warehouses and other buildings where storage conditions are available to ensure their safety and integrity during their shelf life or shelf life.

Process equipment installed in warehouses and other buildings must be equipped with measuring instruments to monitor storage conditions.

Sanitary cleaning (disinfection, disinfection, etc.) should be carried out in warehouses and other buildings where oil products are stored, as well as in refrigerators.

In order to prevent spontaneous combustion of fat products, it is not allowed to store them together with petroleum products, toxic flammable chemicals and other types of fat products that can cause damage.

Requirements for transportation of oil products: Transportation of oil products is carried out in vehicles that ensure their safety and integrity.

Vehicles transporting edible oils and fats must be suitable for these purposes. Transport conditions are determined by the load. These conditions must meet the requirements set by the manufacturer for transportation.

It is not allowed to transport oily products together with cargoes that contaminate their packaging and have a strong (foreign) odor.

\section{Sampling, identification and conformity assessment and testing of oil products:} Identification means the determination of the similarity of the oil products submitted for the purpose of conformity assessment to the accompanying documents and the exact markings indicated on the label.

Identification of fat and oil products is carried out on the basis of product name and (or) characteristics of the product, specified in this Technical Regulation in the description of this product, visually and (or) organoleptic and (or) analytical methods.

Identification of oil products is carried out in one and (or) several ways:

- By name - the name of the oil product specified in the label on the consumer packaging and / or the shipping documents of the product and its use in determining the type of oil products compared with;

- Visual method - by comparing the appearance of a fat-oil product;

- Organoleptic method - is defined by comparing the organoleptic characteristics of fat and oil products with the characteristics of the definition given for these fat products in this Technical regulation. 
The organoleptic method is used without the possibility of naming and visually identifying the fat-oil product. In the presence of signs of microbial spoilage in the product, the evaluation of the organoleptic characteristics of the product is excluded; Naming of oil products from the method of analysis is used when it is impossible to identify by visual or organoleptic methods. test methods of physicochemical parameters (erucic acid, fatty acid content and trans isomers of fatty acids in vegetable oils) are used.

\section{Conformity assessment: Conformity assessment of oil and gas products in accordance with the requirements of standards and technical regulations is carried out in the following forms:}

- Confirmation of conformity of oil products;

- State control (inspection);

- New type of oil - state registration of oil products.

Assessment of compliance of production, storage, transportation and sale of oil products with the requirements of this Technical regulation is carried out in the form of state control (inspection) over compliance with the established requirements for oil products.

Sampling and testing: The necessary test methods for assessing the compliance of oil products with the requirements of the Technical Regulation, as well as sampling methods are carried out in accordance with the regulations in the field of technical regulation.
An increase in the standard of living has led to a change in the attitude of the consumer himself towards food products.

Ensuring and improving the quality and safety of food is an ongoing process, and it should be managed by a well-organized system, the strategy of which is to extend quality management to all structural divisions, and the tactics is to combine new progressive technology with professional training of personnel.

An important issue in the field of ensuring the quality and competitiveness of products is the actualization and harmonization of the requirements and indicators of the national standards of the republic with the requirements of the standards of the international organization ISO and the standards of industrialized countries.

\section{CONCLUSION}

Based on the analysis, ensuring and improving the quality and safety of edible oil, the current system of standardization and assessment of the quality of food products in the republic, sanitary norms and rules, it is recommended that the following measures be taken to improve work for the high-quality and safe organization of edible oil production:

- To comply with the current requirements of the legislative acts of the republic and international norms and rules;

- To organize continuous professional development of executives and engineering and technical specialists;

- To improve educational processes for 
training highly qualified personnel, taking into account modern scientific achievements and advanced manufacturing experience;

- Equipping production processes and testing laboratories for assessing the quality of finished products with timely instrumentation and testing means;

- Harmonizing regulatory documents with the level of requirements of international standards, applying international best practices.

- Continuous improvement of the quality management system.

\section{REFERENCES}

1. Shahidi F, Wanasundara UN. (2002). Methods for measuring oxidative rancidity in fats and oils. Food Lipids Chem Nutr Biotechnol. (17). pp.387-403.

2. Negash, Y. A., Amare, D. E., Bitew, B. D., \& Dagne, H. (2019). Assessment of quality of edible vegetable oils accessed in Gondar City, Northwest Ethiopia. BMC research notes, 12(1), 1-5.

3. Okechalu, J. N., Dashen, M. M., Lar, P. M., Okechalu, B., \& Gushop, T. (2011). Microbiological quality and chemical characteristics of palm oil sold within Jos Metropolis, Plateau State, Nigeria.

4. Mozaffarian, D., \& Clarke, R. (2009). Quantitative effects on cardiovascular risk factors and coronary heart disease risk of replacing partially hydrogenated vegetable oils with other fats and oils. European journal of clinical nutrition, 63(2), S22-S33.
5. Endo, Y. (2018). Analytical methods to evaluate the quality of edible fats and oils: the JOCS standard methods for analysis of fats, oils and related materials (2013) and advanced methods. Journal of oleo science, 67(1), 1-10.

6. Lawson-Wood, K., Seer Green, U. K., Bohman, A., Shelton, C. T., \& Way, K. (2020). Determination of Quality Parameters of Crude Palm Oil using NearInfrared Spectroscopy and Multivariate Analysis.

7. Andrikopoulos, N. K., Dedoussis, G. V., Tzamtzis, V., Chiou, A., \& Boskou, G. (2002). Evaluation of medium polarity materials isolated from fried edible oils by RP-HPLC. European journal of lipid science and technology, 104(2), 110-115.

8. Billek, G. (2000). Health aspects of thermoxidized oils and fats. European Journal of Lipid Science and Technology, 102(8-9), 587-593.

9. Al-Kahtani, H. A. (1991). Survey of quality of used frying oils from restaurants. Journal of the American Oil Chemists Society, 68(11), 857-862.

10. GOST R 50522-93 Table grapes. Cold store guidelines.

11. Statistical Directory of Uzbekistan 2019. Tashkent.

12. Economic Review of the Republic of Uzbekistan No. 8 (236).

13. Resolution of the President of the Republic of Uzbekistan on August 23, 2017, 14. No. PP-3239 "On additional measures to improve the activities of 15. Uzsharobsanoat Joint Stock Company". 